\section{Kraniektomi ved malignt hjerneinfarkt}

Trykkavlastende kraniektomi ved malignt hjerneinfarkt gir like godt resultat uansett hvilken hjernehalvdel som er rammet.

Et hjerneinfarkt med størrelse og/eller plassering som gjør at det er fare for intrakranial herniering, kalles malignt. Kraniektomi, dvs. kirurgisk åpning av hodeskallen, vil redusere dødeligheten, men det har vært uklart om slik behandling har dårligere effekt ved infarkt i den språkdominante hjernehalvdelen enn ved infarkt i den ikkespråkdominante. Vi har nylig publisert en studie der vi sammenlikner forløpet hos slike pasienter operert ved Oslo universitetssykehus, Rikshospitalet (1).

I løpet av 12 år opererte vi 45 pasienter med trykkavlastende kraniektomi. 29 overlevde, og 26 av disse ble fulgt opp i 5,5 år (median). Det var ingen forskjell mellom dem som hadde hatt infarkt i den språkdominante siden og dem som hadde hatt infarkt i den ikke-språkdominante siden hva gjelder nevrologisk funksjon, grad av funksjonshemning, behov for assistanse i dagliglivets aktiviteter, angst og depresjon eller livskvalitet.

Basert på denne studien mener vi at hvilken hjernehalvdel som er rammet ikke bør tillegges betydning ved indikasjonsvurderingen for kraniektomi ved malignt hjerneinfarkt.

\section{Jarle Sundseth}

Nevrokirurgisk avdeling

Oslo universitetssykehus, Rikshospitalet

\section{Litteratur}

1. Sundseth J, Sundseth A, Thommessen B et al. Long-term outcome and quality of life after craniectomy in speech-dominant swollen middle cerebral artery infarction. Neurocrit Care 2014. E-publisert 16.8

\title{
Bedre læring med briller for kinesiske skolebarn
}

\section{Myopi er utbredt hos barn i Kina, men få bruker briller. En ny studie viser effekt av å forsyne elevene med gratis briller via skolen.}

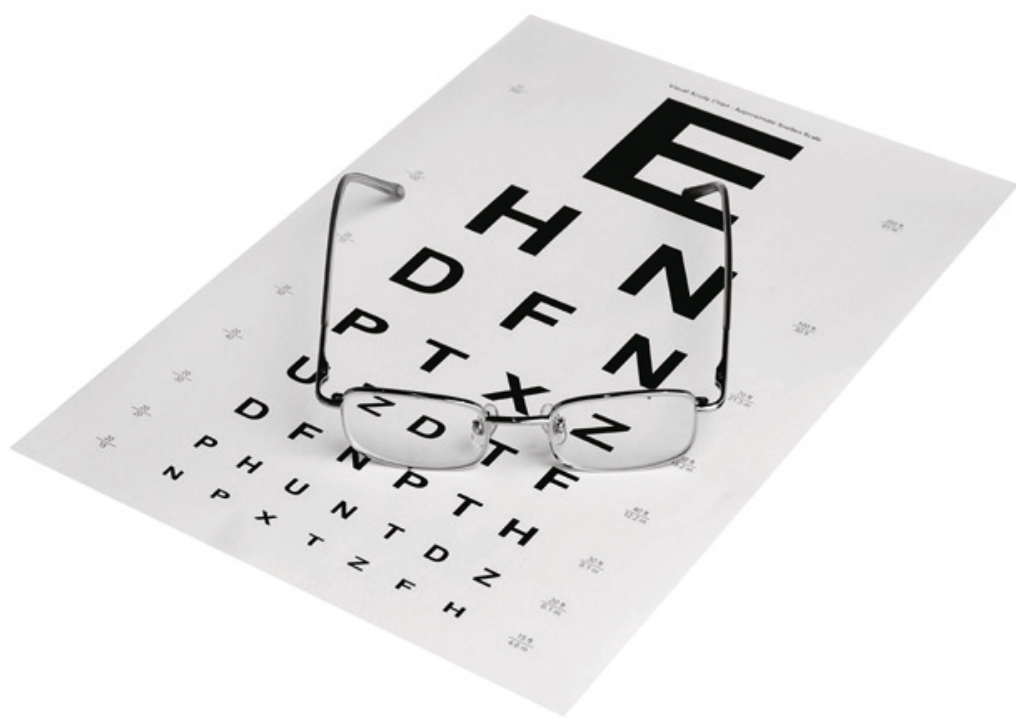

Illustrasjonsfoto: Pixtal/NTB scanpix

I en randomisert, kontrollert studie fra Kina har man undersøkt effekten på faglige prestasjoner av å gi nærsynte skolebarn gratis briller (1). Studien omfattet 252 barneskoler i rurale områder. 19934 barn ble synstestet, og 3177 med ukorrigert visus på 6/12 eller dårligere som var korrigerbart med briller ble inkludert i studien.

Barna ble randomisert skolevis til enten å få gratis briller utdelt på skolen, til å få brilleseddel for utlevering av gratis briller eller til å få vanlig brilleseddel, men ingen gratisbriller.

Ved oppstart av studien (skoleårets begynnelse) brukte $15 \%$ av barna med korrigerbar synsfeil briller. Ved skoleårets slutt ble det observert at $41 \%$ av dem som hadde fått gratis briller på skolen benyttet dem, mot $26 \%$ i gruppen som kun hadde fått vanlig brilleseddel.

De som fikk gratis briller på skolen og de som fikk brilleseddel for utlevering av gratis briller skåret henholdsvis $0,11 \quad 195 \% \mathrm{KI}$ $0,01-0,21)$ og $0,04(95 \% \mathrm{KI}-0,05-0,14)$ standardavvik høyere på en matematikktest ved skoleårets slutt enn de som bare fikk vanlig brilleseddel.
- Studien viser at gratisbriller til skolebarn er effektivt for å forbedre synsfunksjonen, samtidig som skoleprestasjonene blir bedre, sier professor Anna Midelfart ved Norges teknisk-naturvitenskapelige universitet.

- Nærsynthet er meget hyppig i asiatiske befolkninger. I denne studien hadde $24 \%$ av barna nedsatt syn på minst ett øye, og hos en tredel av disse var det ikke mulig å bedre synet med briller. Erfaringen tyder på lavere forekomst av nedsatt, ukorrigert syn hos barn i Norge enn i Asia. Gratis briller til alle barn i Norge som trenger det, vil likevel kunne gi gevinst - både i skolesituasjonen og i familieøkonomien, sier Midelfart.

\section{Matilde Risopatron Berg}

Sykehuset Innlandet, Hamar

Litteratur

MaX, Zhou Z, Yi H et al. Effect of providing free glasses on children's educational outcomes in China: cluster randomized controlled trial. BMJ 2014; 349: g5740. 